\title{
THE CONCEPT OF LENIENCY IN REPUBLIC OF NORTH MACEDONIA
}

\author{
Goran Koevski, PhD, Full professor
}

The Ss. Cyril and Methodius University in Skopje, Faculty of Law, Iustinianus Primus

blvd. Goce Delchev 9B, 1000 Skopje, North Macedonia gkoevski@gmail.com

\author{
Borka Tushevska Gavrilovikj, PhD, Associate professor \\ Faculty of Law, University Goce Delchev Shtip \\ Krste Misirkov 10-A, 2000 Shtip, North Macedonia \\ borka.tusevska@ugd.edu.mk
}

\section{Darko Spasevki, PhD, Associate professor}

The Ss. Cyril and Methodius University in Skopje,

Faculty of Law, Iustinianus Primus

blvd. Goce Delchev 9B, 1000 Skopje, North Macedonia

spasevski_d@yahoo.com

\section{ABSTRACT}

The concept of "leniency" in competition law, or better known as the "leniency programme", has proven to be an extremely important instrument in fighting unfair competition. In the Republic of Northern Macedonia (hereinafter RNM), this concept of suppressing or reducing unfair competition, more or less, exists solely as a law conception. Nowadays, when the EU discusses the impact of the global crisis and the Coronavirus pandemic on the level of utilization of "leniency programme", this concept is still unknown or not a well-known concept for business sector in RNM.

The main focus of this article is "leniency programme" in RNM. The key questions that we aim to answer here, are: whether and to what extent this instrument is predicted in Macedonian competition law? Is it predicted only as a law category, or it has practical implications too? Although this research refers to RNM, we strongly believe that a thorough study of "leniency" requires exploration of European conception of "leniency" too. For that purpose, we use relevant EU legislation, as well as practice. Thus, our main goal is to consider the position of RNM towards "leniency" and bring into relation to the Macedonian competition law. 
We base our hypothetical framework on the assumption that the applicability of "leniency programme" in RNM is at the lowest level. Furthermore, that the undertakings are not interested in applying "leniency". This situation is partly due to the lack of information, the complexity of the application procedure, as well as other factors that are related not only to the attitude of the executive of undertakings, but more to the general economic circumstances, economic development, the market size of goods and services, etc.

Using the analytical-descriptive method, the comparative method, and the method of analysis and synthesis, well elaborate the situation in RNM regarding this issue, and we will present our views considering the questions: whether certain measures should be taken regarding "leniency program", and what should be done to boost the use of this program in the Macedonian business sector.

Keywords: business, competition, fine, cartel, damage, marker.

\section{INTRODUCTORY ASPECTS OF LENIENCY PROGRAMME IN COMPETITION LAW}

\subsection{The importance of competition law and protection from cartel behavior in the market of goods and services}

Competition law is vital in ensuring a free and fair market for goods and services. The protection of competition law is at the top of the agenda of almost every country. This also refers to the EU. The need to provide protection of competition is strongly related to the development of two segments with economic dimension, such as: protection of business, as well as protection of the consumer sector.

Influenced by the immense and speedy turnover of goods and services and the enormous growth of e-commerce, the protection of competition is set as one of the most essential factor for ensuring smooth and real economic growth. ${ }^{1}$ Among the most common types of violations of competition rules, the practice emphasizes cartel activities. These activities generally include fixing purchase or sale prices or other trading conditions, limiting production or establishing sales quotas, dividing markets, negotiating tenders, restricting import or export and / or anti-competitive behavior directed at other companies, competitors of the cartel participants. $^{2}$

1 See: OECD, The role of competition policy in promoting economic recovery, 2020, [www.oecd.org/daf/ competition/the-role-of-competition-policy-in-promoting-economicrecovery-2020.pdf], Accessed 11 April 2021.

2 This definition of "cartel activities" is typical for almost all legal systems, including the Macedonian legal system. According to Macedonian Law on Protection of Competition ("Official Gazette of the Republic of Macedonia" nos. 145/2010, 136/2011, 41/2014, 53/2016 and 83/2018., hereinafter LPC), Article 5, point 11., "Cartels" means all agreements and decisions and / or concerted conduct between two or more undertakings whose purpose is to coordinate their conduct as competitors in the market and / or to influence relevant competition parameters, in particular by fixing purchasing or selling 
In the last decades of the 20th and the beginning of the 21st century, the EU began to pay special attention on creation of an enforcement strategy that deters cartels activities. Taking into account the European statistics regarding the penalties imposed on cartels, its tendency to reduce cartel activities is evident. ${ }^{3}$

Table 1. Fines imposed (not adjusted for Court judgments) - period 2016 - 2020

\begin{tabular}{|c|c|}
\hline Year & Amount In E \\
\hline 2016 & 3726976000 \\
\hline 2017 & 1945656000 \\
\hline 2018 & 800748000 \\
\hline 2019 & 1484877000 \\
\hline$++2020++$ & 288080000 \\
\hline Total & $\mathbf{2 4 6 3 3 7 0 0 0}$ \\
\hline
\end{tabular}

Table 2. Fines imposed (not adjusted for Court judgments) - period 1990 - 2020

\begin{tabular}{|c|c|}
\hline Year & Amount in $\mathbf{€}^{*}$ ) \\
\hline $1990-1994$ & 537491550 \\
\hline $1995-1999$ & 292838000 \\
\hline $2000-2004$ & 3458421100 \\
\hline $2005-2009$ & 9355867500 \\
\hline $2010-2014$ & 7917218674 \\
\hline $2015-2019$ & 8307828000 \\
\hline$++2020++$ & 288080000 \\
\hline Total & $\mathbf{5 7 7 4 4 8 2 4}$ \\
\hline
\end{tabular}

prices or other trading conditions, restriction of production or establishment of sales quotas, division of markets, negotiation of tenders, restriction of import or export and / or anti-competitive behavior directed at other companies - competitors of the cartel participants, in accordance with Article 4 of the Law on Protection of Competition, provides that "cartels".

3 Data taken from the official website of the EU, the section on competition, sub-sector statistics, [https: //ec.europa.eu/competition/cartels/statistics/statistics.pdf], Accessed 25 March 2021. 
Table 3. Ten highest cartel fines per undertaking (since 1969)

\begin{tabular}{|l|l|l|l|}
\hline Year & Undertaking & Case name & Amount in $€^{*}$ \\
\hline 2016 & Daimler & Trucks & 1008766000 \\
\hline$++2017++$ & Scania & Trucks & 880523000 \\
\hline 2016 & DAF & Trucks & 752679000 \\
\hline 2008 & Saint Gobain & Carglass & 715000000 \\
\hline 2012 & Philips & $\begin{array}{l}\text { TV and computer moni- } \\
\text { tor tubes }\end{array}$ & $\begin{array}{l}705296000 \text { of which 391 } \\
\text { ally with LG Electronics }\end{array}$ \\
\hline 2012 & LG Electronics & $\begin{array}{l}\text { TV and computer moni- } \\
\text { tor tubes }\end{array}$ & $\begin{array}{l}687537000 \text { of which 391 } \\
940000 \text { jointly and sever- } \\
\text { ally with Philips }\end{array}$ \\
\hline 2016 & Volvo/Renault Trucks & Trucks & 670448000 \\
\hline 2016 & Iveco & Trucks & 494606000 \\
\hline 2013 & Deutsche Bank & $\begin{array}{l}\text { Euro interest rate deriva- } \\
\text { tives (EIRD) }\end{array}$ & 465861000 \\
\hline 2001 & F. Hoffmann-La Roche & Vitamins & 462000000 \\
\hline
\end{tabular}

Cartels are agreements and/or concerted practices between two or more competitors aimed at coordinating their competitive behaviour on the market and/or influencing the relevant parameters of competition through practices such as the fixing of purchase or selling prices or other trading conditions, the allocation of production or sales quotas, the sharing of markets including bid-rigging, restrictions of imports or exports and/or anti-competitive actions against other competitors. ${ }^{4}$ As we mentioned above, this definition is valid for cartels in almost all legal systems. Each of these systems provides for separate decision-making authorities, in the event of an injury of competition.

Within the EU frame, the competent authority for dealing with competition violations is the Directorate-General for Competition (hereinafter DGC). In the national legal systems, in addition to the courts, the competent authorities for dealing with cartels are national commissions, agencies, etc. Experiences from the practice has shown that detecting cartel behavior of business entities or other undertakings in a broader context, is extremely difficult. The inevitable consequences from the global recession, increased the pressure on the management of the companies and other undertakings broadly, to reach to cartel activities. On the other hand, proving existence of a cartel is not easy. This is commonly due to the management skills and experience in fixing

4 According to Commission Notice on Immunity from fines and reduction of fines in cartel cases, Available from: [https://eur-lex.europa.eu/legal-content/GA/TXT/?uri=CELEX:52006XC1208(04)\#ntc1C_2006298EN.01001701-E0001], Accessed 31 March 2021. 
prices, or sales quotas, or dividing markets etc. Practice shows that cartels are habitually negotiated in strictly discreet spaces and under strictly defined conditions, with the splitting up information between the narrowest circles of managers. ${ }^{5}$

The statistics regarding fines, presented above, clearly show the huge EU ambition to oppose to the cartels. In this regard, there are highly imposed penalties that aim to create a clear perception in the business sector of the mandatory compliance with the competitive legal regime. However, experience shows that the high fines per se, does not present the best model for preventing cartels. The EU is constantly working to modernize its consumer protection strategy / policy and business sector. Because of this ambition, EC implemented many up-to-date instruments, such as: eLeniency online, Anonymous Whistleblower Tool, as well as Management Plan 2020 DG Competition. ${ }^{6}$ All of these activities are part of the EU's overall cartel strategy. In addition, the EU continuously develops its competition legislation too. However, the established EU practices and legal framework for protection of competition, proved to be insufficient for combating cartels. Hence, back in 1996, the EU took concrete steps in the field and created the "leniency programme", as a separate instrument for dealing with cartels. The origins of this concept of cartel protection have been known to the United States since 1978.7 Namely, the Division first implemented a leniency program in 1978, which was substantially revised in $1993 .{ }^{8}$ The Corporate Leniency Policy in USA, was first introduced in 1978 and revised in 1993, and as a model for protection against cartel activities was implemented in the EU.

According to experts, the leniency programme has been successfully practiced in the EU for more than two decades. ${ }^{9}$ Currently, affected by different circumstances, the EU is facing the challenge of effectiveness of leniency programme, focusing on the need of new and additional intervention in the competition legislation. An argument in support of this view, is the fact that the EU invests maximum in the process of facilitating the application procedure, and is working diligently to increase the number of leniency applications. EC constantly bear in mind the new

5 See more for the model of cartels arrangement: [https://ec.europa.eu/competition/cartels/leniency/ leniency.html\#video], Accessed 1 April 2021.

6 See more: [https://ec.europa.eu/competition/cartels/whistleblower/index.html], Accessed 1 April 2021.

7 See more about the genesis, development and status of the leniency programme in the United States: Buffier B.W., Kafele, H.L., Fishbien S., Shearman \& Sterling LLP., Cartel leniency in United States: overview: Available from: [https://uk.practicallaw.thomsonreuters.com/4-501-2185?transitionType=Default\&contextData=(sc.Default)], Accessed 1 April 2021.

8 See: [http://www.oecd.org/corporate/ca/1890449.pdf], Accessed 11 April 2021.

9 Dominte, O., \& Şerban, D., \& Dima, A.M., Cartels in EU: study on the effectiveness of leniency policy," Management \& Marketing, Economic Publishing House, vol. 8(3), 2013, pp.1-24. 
circumstances, including the COVID -19 Pandemic, and notifies the potential participants with required rules referring to the procedure for leniency application.

However, lately, key question is brought to the table among the experts circles: whether the "leniency program" is still the most appropriate model for the prevention, reduction of distortions of competition?! Furthermore, it is a priority to EU to answer the following questions:

- what are the advantages and disadvantages of the application of the "leniency program";

- whether and what measures should be taken in order to improve the efficiency of the implementation of the "leniency program";

- what is the attitude of the European versus the national law of the member states regarding the application of the "leniency program"

- is there effective cooperation between the national bodies for protection against competition competition and the European Commission as a competent body for protection of competition on the European market;

- found the EU border between public and private antitrust enforcement, and what is the contribution of The 2014 EU Directive on damage actions; ${ }^{10}$

- What is the impact of Directive (EU) 2019/1 of the European Parliament and of the Council of 11 December 2018 to empower the competition authorities of the Member States to be more effective enforcers and to ensure the proper functioning of the internal market.

All these questions have raised the need to re-actualize the subject-matter of the "leniency". ${ }^{11}$ Their elaboration from the perspective of the EU legal framework and its impact on the Macedonian competition law will be analyzed below.

\section{LENIENCY PROGRAMME IN EUROPEAN LAW AND POLITICS}

\subsection{Leniency programme in European Competition policy}

The conception and implementation of European competition policy is a complex issue for the EC. In the last decade of the 21st century, the EU faces many challenges in the field of competition law and makes tremendous effort to improve

10 Directive 2014/104/EU of the European Parliament and of the Council of 26 November 2014 on certain rules governing actions for damages under national law for infringements of the competition law provisions of the Member States and of the European Union, available from: [https://eur-lex.europa. eu/legal-content/GA/TXT/?uri=celex:32014L0104], Accessed 5 April 2021.

11 Snyder, B., Chief Executive Officer, Competition Commission of Hong Kong, China, OECD Competition Division, [https://www.youtube.com/watch?v=dJSNoWD0vb8], Accessed on 1 February 2020. 
the quality of equal treatment of undertakings. The presence of the Coronavirus worldwide, has a huge impact on this process. Namely, under the influence of the COVID -19 pandemic, the conditions for realization of the "leniency programme" become easier said than done. As an aggravating circumstance, financial crisis affected the companies, to come to a decision for participating in cartel more easily.

Nevertheless, the EU's position is that competition law must be protected. ${ }^{12}$ According to Margrethe Vestager, "fighting cartels is a very high priority for the European Commission 'owing to the' serious harm cartels cause to consumers and businesses [and to] the economy as a whole in terms of removing incentives to compete on prices or to innovate". . There will be no exception to this positioning of competition policy, regardless of the new circumstances of business operations in the internal market. It is enough to superficially analyze the work of the EC and to see the decisions on which the solutions are based in certain cases" ${ }^{13}$ Based on this position, the proper legislative intervention has been done. ${ }^{14}$

\subsection{Leniency programme from European legislation perspective}

Studying "leniency programme" vie legislative perspective require profound analysis. In EU frame, many relevant provisions should be explored in order to reach to a considerable understanding of this topic. Bearing in mind that our focus is "leniency "in RNM, we are solely going to address those aspects of EU legislation, which we consider relevant for Macedonia issues too. The EU corpus of leniency provisions encompasses regulations, directives, notices etc. ${ }^{15}$ First and foremost,

12 See more about EC activities on protection of competition: [https://ec.europa.eu/competition/antitrust/coronavirus.html], Accessed 10 April 2021.

13 EU Commissioner for Competition: 'Press release Statement 15/5260', 24 June 2015, Available from: [https://thelawreviews.co.uk/title/the-cartels-and-leniency-review/european-union], Accessed 1 April 20201.

14 Palmigiano, P., Penny, L., Competition law and coronavirus: what's the connection, 2020, available form: [https://www.taylorwessing.com/en/insights-and-events/insights/2020/04/competition-law-and-coronavirus-whats-the-connection], Accessed 28 March 2021.

15 It is not possible to analyze the entire EU legal sources which are relevant for "leniency". So, in this article we only will mention them, solely for the purposes of our main research. Such as: Council Regulation (EC) No 1/2003 of 16 December 2002 on the implementation of the rules on competition laid down in Articles 81 and 82 of the Treaty; Directive 2014/104/EU of the European Parliament and of the Council of 26 November 2014 on certain rules governing actions for damages under national law for infringements of the competition law provisions of the Member States and of the European Union; Directive (EU) 2019/1 of the European Parliament and of the Council of 11 December 2018 to empower the competition authorities of the Member States to be more effective enforcers and to ensure the proper functioning of the internal market; Commission Regulation (EU) 2015/1348 of 3 August 2015 amending Regulation (EC) No 773/2004 relating to the conduct of proceedings by the Commis- 
article 101 TFEU (formerly Article 81 of the TEC) is applicable in case of establishing a cartel or applying the leniency programme. ${ }^{16}$ According to this article, the following shall be prohibited as incompatible with the internal market: all agreements between undertakings, decisions by associations of undertakings and concerted practices which may affect trade between Member States and which have as their object or effect the prevention, restriction or distortion of competition within the internal market, and in particular those which:

(a) directly or indirectly fix purchase or selling prices or any other trading conditions;

(b) limit or control production, markets, technical development, or investment;

(c) share markets or sources of supply;

(d) apply dissimilar conditions to equivalent transactions with other trading parties, thereby placing them at a competitive disadvantage;

(e) make the conclusion of contracts subject to acceptance by the other parties of supplementary obligations which, by their nature or according to commercial usage, have no connection with the subject of such contracts.

Any agreements or decisions prohibited pursuant to this Article shall be automatically void.

The provisions of paragraph 1 may, however, be declared inapplicable in the case of:

- any agreement or category of agreements between undertakings,

- any decision or category of decisions by associations of undertakings,

- any concerted practice or category of concerted practices,

which contributes to improving the production or distribution of goods or to promoting technical or economic progress, while allowing consumers a fair share of the resulting benefit, and which does not:

(a) impose on the undertakings concerned restrictions which are not indispensable to the attainment of these objectives;

sion pursuant to Articles 81 and 82 of the EC Treaty; Directive (EU) 2019/1937 of 23 October 2019 of the European Parliament and of the Council on the protection of persons who report breaches of Union law; Commission's Notice on co-operation within the network of competition authorities (OJ 2004 C101/43) (ECN Notice).

16 Consolidated version of the treaty on the functioning of the European Union - part three: union policies and internal actions - title vii: common rules on competition, taxation and approximation of laws - chapter 1: rules on competition - section 1: rules applying to undertakings - article 101 (ex article 81 tec). 
(b) afford such undertakings the possibility of eliminating competition in respect of a substantial part of the products in question.

The early development of the "leniency program" in the EU is formally linked to the adoption of the Commission Notice on the non-imposition or reduction of fines in cartel cases, which is a consequence of the previously established need to prevent or reduce cartel behavior. ${ }^{17}$ This need has been identified as one of the core objectives of the EC, recorded in the 1993 White Paper on Growth, Competitiveness and Employment. ${ }^{18}$

Fully aware of the role of the consumer sector and the value of the free market for goods and services, in the introduction of 1996 Commission Notice on nonimposition or reduction of fines in cartel cases, EC emphasized that consumer protection and the provision of a free market for goods and services, exceeds the interest in punishing the participants in the cartel. 1996 Commission Notice on the non-imposition or reduction of fines in cartel cases, contributes to the establishment of the basic concepts of application of the "leniency program" in a large extent. Well acquainted with the need for amendments to this document, it announces the readiness for constant interventions in accordance with the new trends in the field. In point 3 from 1996 Commission Notice, it announces that "The Commission will examine whether it is necessary to modify this notice as soon as it has acquired sufficient experience in applying it."

The essential value of the 1996 Commission Notice is the criterias that it predict, according to which a certain entity can be exempted from a fine, or to have a reduced value of the fine to be paid in the name of a misdemeanor. ${ }^{19} \mathrm{~A}$ part from this, section E of the 1996 Commission Notice provides the procedure for implementing the leniency application, step by step, until the final completion. It is noteworthy that in this version of the EC Notice, the protection of applicants is not taken into account, in terms of the statements they make before the DGC. In this regard, 1996 Commission Notice emphasized: "The fact that leniency in

17 Original text is available from: [https:/eur-lex.europa.eu/legal-content/EN/ALL/?uri=CELEX\%3A31996Y0718\%2801\%29], Accessed 31 March 2021.

18 White paper, European Commission., Growth, competitiveness, and employment., The challenges and ways forward into the 21st century, COM (93) 700 final. Brussels: 05.12.1993. [https://www.cvce.eu/ content/publication/1997/10/13/b0633a76-4cd7-497f-9da1-4db3dbbb56e8/publishable_en.pdf], Accessed 1 April 2021.

19 When determining the conditions under which the subject may be exempted or request a reduction of the fine, the document qualifies into three categories: non-imposition of a fine or a very substantial reduction in its amount, substantial reduction in a fine, significant reduction in a fine. This qualification is just another confirmation of the EU's commitment to include as many entities as possible, which through their participation in the leniency program, will contribute to reducing cartel behavior. 
respect of fines is granted cannot, however, protect an enterprise from the civil law consequences of its participation in an illegal agreement. In this respect, if the information provided by the enterprise leads the Commission to take a decision pursuant to Article 85 (1) of the EC Treaty, the enterprise benefiting from the leniency in respect of the fine will also be named in that decision as having infringed the Treaty and will have the part it played described in full therein. The fact that the enterprise cooperated with the Commission will also be indicated in the decision, so as to explain the reason for the non-imposition or reduction of the fine". Practice has shown that this solution is not the most appropriate, given the fact that exactly this moment (the position in the civil litigation) is perceived by experts as one of the main reasons why undertakings are in a dilemma whether to report the existence of a cartel or participate in it.

The EC desire to enriched the effectiveness of the "leniency programme", contributed to the implementation of the concept of the Anonymous Whistleblower Tool. ${ }^{20}$ According to this concept, since 2017, the possibility has been established for every individual who has knowledge of practicing cartel behavior by certain entities, to report it. This also serves to relieve national courts from resolving cases. In 2002, citing point 3 of the introduction of 1996 Commission notice, EC adopted the Commission notice on immunity from fines and reduction of fines in cartel cases Official Journal C $045,19 / 02 / 2002$ P. $0003-0005 .{ }^{21}$ Totally aware of the need for constant changes of the legal framework, the 2002 Commission Notice anticipates: the Commission announced that it would examine whether it was necessary to modify the notice once it had acquired sufficient experience in applying it. After five years of implementation, the Commission has the experience necessary to modify its policy in this matter. Whilst the validity of the principles governing the notice has been confirmed, experience has shown that its effectiveness would be improved by an increase in the transparency and certainty of the conditions on which any reduction of fines will be granted. A closer alignment between the level of reduction of fines and the value of a company's contribution to establishing the infringement could also increase this effectiveness.

Today's procedure for leniency is conducting under Commission Notice on immunity from fines and reduction of fines in cartel cases (OJ 2006 C298/17) (2006

20 When determining the conditions under which the subject may be exempted or request a reduction of the fine, the document qualifies into three categories: non-imposition of a fine or a very substantial reduction in its amount, substantial reduction in a fine, significant reduction in a fine. This qualification is just another confirmation of the EU's commitment to include as many entities as possible, which through their participation in the leniency program, will contribute to reducing cartel behaviour.

21 See: [https://eur-lex.europa.eu/legal-content/EN/ALL/?uri=CELEX\%3A52002XC0219\%2802\%29], Accessed 11 April 2021. 
Leniency Notice). ${ }^{22}$ This Notice sets out the framework for rewarding cooperation in the Commission investigation by undertakings which are or have been party to secret cartels affecting the Community. According to 2006 Leniency Notice, point (8(a)), the Commission will grant immunity from any fine which would otherwise have been imposed to an undertaking disclosing its participation in an alleged cartel affecting the Community if that undertaking is the first to submit information and evidence which in the Commission's view will enable it to:

(a) carry out a targeted inspection in connection with the alleged cartel, or;

(b) find an infringement of Article $81 \mathrm{EC}$ in connection with the alleged cartel.

Immunity pursuant to point (8)(a) will not be granted if, at the time of the submission, the Commission had already sufficient evidence to adopt a decision to carry out an inspection in connection with the alleged cartel or had already carried out such an inspection. As well, Immunity pursuant to point (8)(b) will only be granted on the cumulative conditions that the Commission did not have, at the time of the submission, sufficient evidence to find an infringement of Article $81 \mathrm{EC}$ in connection with the alleged cartel and that no undertaking had been granted conditional immunity from fines under point (8)(a) in connection with the alleged cartel. In order to qualify, an undertaking must be the first to provide contemporaneous, incriminating evidence of the alleged cartel as well as a corporate statement containing the kind of information specified in point (9)(a), which would enable the Commission to find an infringement of Article 81 EC. Yet, these conditions are not the only requirements that should be fulfilled. ${ }^{23}$

2006 Leniency Notice also predict the possibility of using reduction of fine under certain conditions. ${ }^{24}$ Finally, the 2006 Commission Notice gives an answer to one of the most essential questions that has a strong impact on companies in deciding whether to use the leniency program, and that is the position of these companies in civil proceedings. Namely, according to point 39, from 2006 Commission Notice, in line with the Commission's practice, the fact that an undertaking cooperated with the Commission during its administrative procedure will be indicated in any decision, so as to explain the reason for the immunity or reduction of the fine. The fact that immunity or reduction in respect of fines is granted cannot protect an undertaking from the civil law consequences of its participation in an infringement of Article $81 \mathrm{EC}$. All these issues that we only opened in this part of the article, are crucial for the maintenance and development "leniency" under

\footnotetext{
22 Published on 8 December 2006 and subsequently amended on 5 August 2015.

23 In order not to burden too much this part of elaboration, see more about the additional condition for getting leniency in the 2006 Commission Notice.

242006 Commission Notice, Part III, point 23, Requirements to qualify for reduction of a fine.
} 
the new circumstances. So, in the part dedicated to Macedonia, we are going to take them in mind, as a most suitable way to understand the situation in RNM, regarding "leniency".

\section{LENIENCY IN MACEDONIAN COMPETITION LAW}

\subsection{Legal framework for leniency in Macedonian competition law}

Comparative study of "leniency programme", points out that European experts for cartels, still perceive leniency as the most effective tool for detecting and combating cartels. ${ }^{25}$ Theoretically, numerous debates, conferences and roundtables related to "leniency" have been focused on the question: how to motivate participants in cartel to report and to take advantage of the leniency?! This is strongly related to the efforts, achievements and success of this programme. ${ }^{26} \mathrm{Via}$ leniency programme, EC exempt many companies from fines. For example, in cases, EU Canned Vegetables (Case COMP/AT.40127); Forex (Case COMP/AT.40135); Occupant Safety Systems (Case COMP/AT.40481), DGC exonerate these companies from a huge amount of fines. ${ }^{27}$

As we have seen from the theoretical elaboration above in the text, the EC continuously takes numerous actions to increase leniency applications. The best proof for this standpoint is the fact that right away after the declaration of the pandemic, many changes were made on the official website of the EC in the field of applications, such as: notifying the possibility of submitting oral notifications, elaborating the stages of the procedure, news required documents were attached etc. ${ }^{28}$

"Leniency programme", is not an unknown concept in the Macedonian law. Namely, Article 65 of the LPC of RNM explicitly provides for the concept of exemption or reduction of the fine (leniency). More precisely, in Article 64 of the LPC, in the part titled as "fine assessment", the Commission for deciding on

25 Ysewyn, J., Boudet, J., Leniency and competition law: An overview of EU and national case law Procedures, agreement, all business sectors, sanctions / fines / penal ties, leniency, foreword, Art. $\mathrm{N}^{\circ} 72355,2018$, [https://www.covcompetition.com/wp-content/uploads/sites/21/2018/08/here-1.pdf], Accessed 29 March 2021.

26 For cartel infringements, the largest fine imposed on a single company is over $€ 896$ million; the largest fine imposed on all members of a single cartel is over $€ 1,3$ billion. Available from: [https://ec.europa. eu/competition/cartels/leniency/leniency.html], Accessed 1 March 2021.

27 The original text of the decisions of the European Commission is available from: [https://uk.practicallaw.thomsonreuters.com/0-517-4976?transitionType=Default\&contextData=(sc.Default)\&firstPage=true\#co_anchor_a774715], Accessed 11 April 2021.

28 A special document is available on the official website, which contains data on the exact stages of the procedure in case of submitting an application, which now can not be in oral form: [https://Ec.Europa. Eu/Competition/Cartels/Leniency/Oral_Statements_Procedure_En.Pdf], Accessed, 1 April 2021. 
misdemeanors (hereinafter CDM) within the Commission for protection of competition (hereinafter CPC), treats leniency as a mitigating circumstance in the assessment of the fine. Additionally, the essential concept of the leniency program is contained in Article 65 of the LPC. The Leniency program refers only to detection and suppression of cartels, and not in any other forms of distortion of competition. In Article 7 of the LPC, the legislator explicitly stated what a cartel is, and in what forms it occurs. Compared to defining a cartel in other relevant legal sources, difference are not encountered. ${ }^{29}$

According to Macedonian law, any direct or indirect fixation of the purchase or sale price or some other trading conditions is a cartel; further, any activity that restricts or controls production, market, technical development or investment, any activity that means market sharing or sources of supply is a cartel; further, any conduct which implies the application of different conditions for the same or similar legal matters with other trading partners, which puts them in a less favorable competitive position or any activity which conditioned the conclusion of the contracts by accepting from the other contracting parties additional obligations, which after their nature or in accordance with commercial customs are not related to the subject of the contract. All these behaviors present cartels activities and are prohibited within the meaning of Article 7 (paragraph 1) of the LPC. Any agreement, decision, or individual provision of the agreements, which are guaranteed in this sense, do not produce legal effect, i.e., are null and void. ${ }^{30}$

In order to reduce the scope and dynamics of cartel activities, the LPC, among other things, provides for "leniency programme". According to the legal wording of Article 65, in order to detect cartels that constitute violations of Article 59 paragraph (1) item 1) of the LPC, the Commission for deciding on a misdemeanor at the request of a company that has recognized its participation in a cartel will de-

29 In this context the definition from the Commission Notice on Immunity from fines and reduction of fines in cartel cases: Cartels are agreements and/or concerted practices between two or more competitors aimed at coordinating their competitive behaviour on the market and/or influencing the relevant parameters of competition through practices such as the fixing of purchase or selling prices or other trading conditions, the allocation of production or sales quotas, the sharing of markets including bid-rigging, restrictions of imports or exports and/or anti-competitive actions against other competitors. [https://eur-lex.europa.eu/LexUriServ/LexUriServ.do?uri=OJ:C:2006:298:0017:0022:EN:PDF], Accessed 15 March 2021.

30 Following the example of EU solutions and comparative solutions of other systems, an exception to the application of this prohibition is in contracts, decisions of associations of undertakings and concerted conduct that contribute to improving the production or distribution of goods or services or promoting technical or economic development, provided that consumers also benefit from it proportionately. See Article 7 paragraph 3 of the LPC. 
termine full exemption from fine, which as a rule should have been pronounced to that company if the same:

1) first submit evidence that enables the Commission for deciding on a misdemeanor to initiate a misdemeanor procedure or

2) first submit evidence that enables the Commission for deciding on a misdemeanor to complete the already initiated misdemeanor procedure with a decision that determines the existence of a misdemeanor, if without such evidence the existence of the misdemeanor could not be determined.

Article 65 from LPC lay down the conditions that must be fulfilled for "leniency". The LPC also envisages the concept of reduction from fines, and the conditions that must be accomplished to apply for it. In this regard, if the company that has admitted its participation in a cartel which is a misdemeanor under Article 59 paragraph (1) item 1) of the LPC, does not meet the conditions for full exemption from the fine from paragraph (1) of the LPC, the fine A rule that should have been imposed on him may be reduced if he submits to the CDM relevant evidence of decisive importance for making a decision that determines the existence of a misdemeanor.

The immunity, that is, the reduction of the fine referred to in paragraphs (1) and (2) of the article 65, shall apply if the undertaking requesting immunity, that is, reduction of the fine cumulatively meets the following requirements:

1) terminates its participation in the cartel immediately after the submission of the request for immunity from a fine;

2) cooperates with the Misdemeanor Commission fully, on a continuous basis, and submits the necessary data in the shortest possible time period;

3) does not notify the other participants in the cartel about the submission of the request for immunity from a fine;

4) prior to the submission of the request for immunity from a fine, does not disclose the existence or content of the request, except to bodies responsible for sanctioning the cartel outside the Republic of Macedonia, and

5) does not destroy, conceal or falsify relevant evidence used to establish facts being of importance for making a decision by the Misdemeanor Commission.

(4) The Misdemeanor Commission shall not grant full immunity from a fine to the undertaking referred to in paragraph (1) of this Article which throughout the duration of the cartel has taken measures by which it has forced the other undertakings to participate or remain therein, but may determine reduction of the fine if such undertaking meets the requirements referred to in paragraph (3) of this Article. 
The Government of the Republic of Macedonia, on the proposal of the Commission for Protection of Competition, shall prescribe in more detail the conditions and the procedure under which the Commission for deciding on misdemeanors decides on exemption or reduction of the fine. In this regard, the Decree on closer conditions for exemption or reduction of the fine and the procedure under which the CDM decides is applied. ${ }^{31}$ A government decree is an act transposing Commission Notice on Immunity from fines and reduction of fines in cartel cases (52006XC1208(04).

This Decree does not exclude the application of Article 58 of the LPC, according to which if damage is caused by any action that constitutes a misdemeanor, the person who will suffer damage may seek compensation in accordance with the Law on Competition.

The Government Decree of 2012 envisages all phases of the implementation of the leniency procedure, as follows:

- Request for exemption from fine

- Conditions for exemption from fine

- Other conditions for exemption from fine

- The action of the CDM upon the request for exemption from fine, and

- Notification of compliance with the conditions for exemption from fine.

According to the Decree of 2012, the company requesting exemption from fine in accordance with Article 65 paragraph (1) item 1) or 2) of the LPC, should submit a request for exemption from fine to the CDM. The company must submit the following evidence to the request for exemption from fine:

a) A statement by the undertaking referred to in Article 3 of the Regulation acknowledging its participation in the cartel; and

(b) Other evidence, cartel related, held or available to the company seeking exemption from the fine at the time of filing, including in particular evidence dating to the time of the cartel.

Article 5 of the Decree explicitly provides for the conditions for exemption from fines. In this sense, the CPC shall determine a fine exemption in accordance with Article 65 paragraph (1) item 1) of the LCP, provided that at the time of filing the request for a fine exemption, the $\mathrm{CPC}$ did not have sufficient evidence to initiate a misdemeanor procedure or no misdemeanor was initiated procedure related to the

31 The whole text of the Decree RNM., 6p:41/2012 from 26.03.2012, is available from: [https://dejure.mk/zakon/uredba-za-pobliskite-uslovi-za-osloboduvanje-ili-namaluvanje-na-globata-i-postapkata-pod-koja-komisijata-za-odluchuvanje-po-prekrshok-odluchuva-za-osl], Accessed 25 March 2021. 
cartel in question. CDM will determine exemption from fine, in accordance with Article 65 paragraph (1) item 2) of the LPC, in favor of the company requesting exemption from fine if the following conditions are met: a) at the time of submitting the request for exemption from fine KOP did not have sufficient evidence to make a decision establishing the existence of the cartel for which the request is submitted;

b) no other undertaking which first submitted evidence which enabled the KOP to initiate a misdemeanor procedure for a cartel was not granted a conditional exemption from the fine referred to in Article 9 paragraph (1) of this Regulation; and

c) the undertaking requesting exemption from the fine is the first to provide evidence dating back to the time of the cartel and prove its existence and submit a statement to the company referred to in Article 3 of this Regulation, which will enable the COP to complete the procedure by adopting of a decision determining the existence of a misdemeanor.

Apart from this conditions, laid down in article $65 \mathrm{LPC}$, and articles 2 and 5 from the Decree 2012, the undertaking requesting exemption from the fine must also meet the following conditions:

a) to submit to the CDM continuously and in the shortest possible time accurate, unambiguous and complete information from the moment of submitting the request for exemption from fine and during the entire procedure, i.e:

1) to submit to CDM all relevant information and evidence about the cartel that it owns or that are available to it as soon as possible;

2) be fully available to the CDM to respond to any requests that may contribute to the establishment of the facts as soon as possible; - to ensure the availability of existing, and if possible former, employees and directors for giving statements and explanations on the minutes before the CDM;

3) not to destroy, falsify or conceal relevant information or evidence relating to the cartel, and

4) not to disclose the fact that he has submitted a request for exemption from fine to the COP, nor to disclose the content or part of its content until the COP submits a preliminary report on the established factual situation in accordance with Article 42 paragraph (1) of the LPC, except unless otherwise agreed between the CDM and the company seeking exemption from the fine; ${ }^{32}$

32 In order to give the participants in the procedure the opportunity to state the facts and circumstances of importance for determining the factual situation, the Commission for deciding on a misdemeanour, 
b) terminate his participation in the cartel immediately after submitting the request for exemption from fine, unless the continuation of his participation in the cartel, in the opinion of the COP, is necessary for the successful completion of the procedure; and

c) during the preparation of the request for exemption from fine has not destroyed, falsified or concealed evidence of the cartel, nor has it revealed the fact, or any part of the content of the request that it intends to submit, except to other bodies responsible for sanctioning the cartel outside the Republic of Macedonia.

CDM may reject the request for exemption from a fine submitted in accordance with Article 65 paragraph (1) item (1) or (2) of the LPC if it is submitted after the CDM has submitted a preliminary notification on the established factual situation. ${ }^{33}$

Regarding the treatment of CDM in relation to the leniency application, the predicted solutions express the implementation of a marker system. ${ }^{34}$ This system enables the preservation of the applicant's place in terms of obtaining exemption. ${ }^{35}$ In this sense, the decision of the Decree according to which the company requesting exemption from fine in accordance with Article 65 paragraph (1) item 1) or 2) of the LPC, may submit a notice of intention to file a request for exemption before submitting the request for exemption from fine.

For the submitted notification, CDM issues a certificate which keeps the place of the submitter of the waiting list for exemption from fine, for a period determined individually from case to case, in order to enable the submitter of the notification to obtain the necessary data and evidence (marker). In the confirmation, CDM determines the deadline within which the submitter of the notification is obliged to submit a request for exemption from the fine referred to in Article 2 of this Regulation. If the submitter of the notification has submitted the request for exemption from the fine within the deadline determined by the CDM, the request for exemption from the fine shall be considered submitted on the date of issuance of the certificate. If the submitter of the notification has not submitted a request for exemption from the fine within the determined deadline, the CDM may freely

before scheduling an oral hearing, submits to the participants a preliminary notification on the established factual situation.

33 See article 6 from the LPC.

34 Lacerda, Aranha, J. F., The Leniency Programs and the Creation of a One-Stop Shop for Markers, RDC, Vol. 2, no 2, November, 2014, pp. 64-75.

35 See more: [http://www.oecd.org/daf/competition/markers-in-leniency-programmes.htm\#:-:tex$\mathrm{t}=$ Marker\%20systems\%20allow\%20a\%20prospective,period\%20of\%20time\%2C\%20while\%20 the], Accessed 28 March 2021. 
dispose of the data and evidence submitted with the notification, for which he/she shall notify the submitter of the notification in writing.

The Decree envisages the whole procedure of CDM (Article 8). According to this, at the request of the undertaking seeking for exemption from fine, CDM issues a receipt which confirms the date and, if possible, the time of receipt of the request for exemption from the fine. CDM will not decide on a request for release from a fine before deciding on a previously submitted request for release from a fine related to the same cartel, whether it is a request or notification of intent to file a request for release.

CDM is obliged to inform the applicant about the results after the submitted application. Hence, in accordance with Article 9, when the CDM determines that the undertaking seeking exemption from the fine meets the requirements of Article 65 paragraph (1) item 1) or 2) of the LPC and Articles 2 and 5 of this Regulation, it shall notify it in writing. In case when the conditions are not met, CDM will notify the applicant in writing. In this case, the company seeking exemption from the fine may withdraw the evidence submitted in support of the request for exemption, or to request from CDM to treat the documentations as a request for reduction of the fine. This does not prevent the CDM from taking action ex officio in order to gather the necessary evidence.

The CPC's action on the request for exemption or reduction of a fine, including the definition of specific activities, terms and criteria useful for the procedure, is also provided in the CPC guidelines for exemption or reduction of the fine, which are adopted by the CPC alongside with 14 other Guidelines and Guide for Detecting Illegal Contracting in Public Procurement Procedures. ${ }^{36}$ In 29 points of the guidelines, the CPC provides for the procedure and includes the definition of certain aspects that can not be found in the JCC and the Decree. Hence, the importance of the same in terms of successful practical implementation of leniency.

The analysis of the LPC in the part of the leniency programme, as well as the analysis of the Decree and the Guidelines, indicates the fact that in a normative sense the concept of the "leniency programme" is fully implemented in RNM. In the practice of business operations and in the practice of the CPC, the picture is quite different. Namely, from the research we conducted in the business sector,

36 In this regard, for example, is the definition of a key criterion for determining the amount of the fine reduction. Namely, according to the guidelines, that will be the total added value of the evidence provided by the applicant for reduction of the fine. This is particularly important in terms of whether the evidence submitted by the company constitutes evidence of significant added value in relation to the evidence already available to the CDM. CDM will also take into account the overall level of cooperation provided. 
and from the research of the work of the CPC in the area of leniency, we found a large discrepancy between the use of this programme and its law anticipation.

To get more information about the usefulness and effectiveness of the leniency, we approach to the $\mathrm{CPC}$ with several relevant questions, as follows:

\begin{tabular}{|c|c|}
\hline $\begin{array}{l}\text { In how many cases, in the last } 10 \text { years }(2010-2020) \text { the } \\
\text { commission for deciding on a misdemeanor within the } \\
\text { CPC, has made a decision to exempt companies from fines, } \\
\text { based on the leniency program in terms of Article } 65 \text { (ex- } \\
\text { emption or reduction of the fine) leniency) of the Law on } \\
\text { Protection of Competition („Official Gazette of the Re- } \\
\text { public of Macedonia“ No. } 145 / 2010 ; 136 / 2011 ; 41 / 2014 \text {; } \\
53 / 2016 \text { and } 83 / 2018) \text {. }\end{array}$ & $\begin{array}{l}\text { The Commission for deciding } \\
\text { on misdemeanors at the CPC, } \\
\text { in the last } 10 \text { years, has not } \\
\text { made a decision on exemption } \\
\text { from fines under Article } 65 \text { of } \\
\text { the CPC. }\end{array}$ \\
\hline $\begin{array}{l}\text { In how many cases, in the last } 10 \text { years }(2010-2020) \text { the } \\
\text { commission for deciding on misdemeanors within the } \\
\text { CPC, has made a decision to reduce the fine of compa- } \\
\text { nies, based on the leniency program in terms of Article } 65 \\
\text { (exemption or reduction of the fine) leniency) of the Law } \\
\text { on Protection of Competition ("Official Gazette of the } \\
\text { Republic Macedonia" No. 145/2010;136/2011; 41/2014; } \\
\text { 53/2016;83/2018). }\end{array}$ & $\begin{array}{l}\text { The Commission for decid- } \\
\text { ing on misdemeanors at the } \\
\mathrm{CPC} \text {, in the last } 10 \text { years, has } \\
\text { not made a decision to reduce } \\
\text { the fine under Article } 65 \text { of the } \\
\text { CPC. }\end{array}$ \\
\hline $\begin{array}{l}\text { How many companies in RNM in the last } 10 \text { years ( } 2010 \text { - } \\
2020 \text { ) have requested reduction or exemption from fine } \\
\text { in terms of Article } 65 \text { of the LPC, based on the leniency } \\
\text { program. }\end{array}$ & $\begin{array}{l}\text { So far, the CPC has not sub- } \\
\text { mitted requests for exemption } \\
\text { or reduction of the fine on the } \\
\text { basis of cartel detection, i.e., in } \\
\text { terms of Article } 65 \text { of the CPC, } \\
\text { i.e., application for leniency } \\
\text { program. }\end{array}$ \\
\hline $\begin{array}{l}\text { How many companies in RNM in the last } 5 \text { years submit- } \\
\text { ted a request for exemption or reduction of the fine in } \\
\text { terms of Article } 65 \text { of the LPC, however, did not cooperate } \\
\text { with the CPC completely, continuously, i.e., provided the } \\
\text { necessary data with a delay. }\end{array}$ & $\begin{array}{l}\text { No such requests have been } \\
\text { submitted to the CPC so far. }\end{array}$ \\
\hline
\end{tabular}

Taking into account the answers from the authorities in the CPC, we conclude that in the RNM this programme has no practical dimension. This is not surprising. From the interview with an employee of the CPC, we received information that only one company in 2018 ask if it can use leniency, but never started a procedure. Accordint to the data from the CPC, the potential applicant found this appication as very complex.

For the needs of the leniency research, we conducted research in over 120 companies registered in the territory of RNM. The research was mainly based on gathering information about: 
- have they heard of the leniency program;

- are they familiar with the possibilities that leniency provides for its users;

- do they consider it a useful tool in the fight against cartelism;

- do they consider to use this programme.

We contacted 120 companies registered in the territory of RNM. Twenty seven (27) companies showed willingness to answer the questions. From these, eighteen (18) had never heard of leniency, and nine (9) companies said they knew the program, but had little knowledge of the benefits of using it.

The low level of interest in participating in this programme is clearly stated in the EC report from 2020. Namely, among other shortcomings and indications, the EC noted that "leniency" is has not been implemented in RNM in practice. According to the report, North Macedonia's legislative framework is broadly aligned with the EU acquis in the area of antitrust and mergers, though some remaining pieces of implementing legislation have yet to be aligned. On antitrust, there is no leniency policy towards whistle-blowers. On implementation, the number of merger decisions decreased from 61 in 2018 to 49 in 2019 and the number of decisions adopted on cartels and abuse of dominant position dropped from 5 in 2018 to 3 in 2019. The CPC should improve its enforcement record by increasing on-site inspections and by using the leniency instrument more often. It should also continue to make full and transparent use of the possibility of fining, if applicable. The lack of capacity of the CPC and of courts dealing with anti-trust cases hinders proper enforcement.

Taking into account the data obtained by the CPC, and the situation in the business sector, the main questions is imposed: why leniency is not use in RNM? Given the specificity of leniency, and in general the competition law for each national economy, we can't ignore the question of the justification of the application of "leniency" in the economies with different scope and scale. Namely, in our opinion, the legal regime of a large number of issues in the field of competition law that are regulated in the EU and worldwide, must not be automatically applied in economies of different type and scope, including RNM. More precisely, there is no efficiency in the bare implementation of EU legislation, in circumstances when the conditions for EU solutions are not matured, and there is still no business climate for them. ${ }^{37}$ However, in terms of leniency, we made a more

37 More about the need of different legal regime in competition law in the small economy countries see: Gal. M. S., Competition policy for small Market Economies, Institute of Developing, Economies, Japan External Trade organization, Vol.42, n.1, 2004, pp.113-118. Available from: [file://C:/Users/ User/AppData/Local/Packages/Microsoft.MicrosoftEdge.8wekyb3d8bbwe/TempState/Downloads/ ZDE200403-006\%20(1)pdf], Accessed 1 March 2021. 
thorough analysis and quite easily and with great certainty we can say that the state of RNM in terms of the degree of implementation of leniency, negatively affects the economic situation, and seriously endangers consumer rights. ${ }^{38}$ Hence, there is no reason for not using this program, arguing that it is an unsuitable tool for countries with low economic turnover.

Analyzing the CPC reports, in the part of violation of Article 7 and ascertainment of cartel behavior, there are many cases which according to the Macedonian economy show serious distortion of competition. The data from the annual reports of the CPC show that there are forms of cartel behavior and that the CPC continuously acts on such cases and imposes fines. For example, only in 2018, the CPC imposes a total amount of 11,036,936.00 denars, imposing a fine on Makedonski Telekom, Prilepska Pivarnica, Institute of Accountants and Certified Accountants for RSM, etc. ${ }^{39}$

Cartels have been detected in the pharmacy industry too. Commission imposed fine in total amount of 5570.146,00 Euros on two crucial wholesalers. One of cases is known as Alkaloid Cons and Dr. Panovski case. In this case the CPC declared fine for concerted practices, during the submission of bids for the generic drug Etoposide. The concerted practice was ascertained in the tender procedure announced by the PHI University Radiotherapy and Oncology Clinic Skopje, PHI University Clinic of Pediatric Diseases, Skopje, PHI University Clinic. Trifun Panovski "Bitolain" 2011. Namely, in the purchase made by hospitals, Alkaloid Cons and Dr.Panovski provided identical prices for the generic drug Etoposide (injections / vials of $100 \mathrm{mg}, 100 \mathrm{ml}, 100 \mathrm{mg} / 5 \mathrm{ml}$ and $20 \mathrm{mg} / \mathrm{ml}$ ). The bids submitted with the said drugs coincided completely up to 2 decimals. Such matching of the offered prices exists only in the case of concerted practice. Pursuant to Article 59 (1) and in conjunction with article 7 (1) of the Law on Protection of Competition, concerted practice is forbidden..$^{40}$ In 2012, on the same grounds, with a fine of $€ 770,000,00$ these two participants were penalized for concerted practice in public procurement bid for Docetaxel. ${ }^{41}$ The practice revealed that these two CPC solutions have influenced other pharmaceutical companies, as prevention for further potential bargaining and concerted practice. Alkaloid is one

38 Tusevska Gavrilovikj, B., Competition law in Republic of North Macedonia, Faculty of Law, Osjek, 2020.

39 In order not to burden the text, in this section we do not enter the data from the reports for the last 10 years. They are available at: [http://kzk.gov.mk/category/konkurencija-obrasci-informacii-resursi/], Accessed 28 March 2021.

40 The case was downloaded from the official website of the Commission for protection of competition. See: [http://kzk.gov.mk/wp-content/uploads/2019/03/Globa-za-lekot-etoposide.pdf], Accessed 1April 2021.

${ }_{41}$ See the full text of the case at the official website of the CPC: [http://kzk.gov.mk] Accessed 8 April 2021. 
of the biggest pharmaceutical companies in RNM; hence this decision cannot be ignored in the pharmaceutical industry.

Bearing in mind this situation, our opinion is that the RNM should seriously pay attention on the implementation and effectiveness of leniency programme. In this context, some suggestions will be given in the conclusions.

\section{CONCLUSION}

Analyzing "leniency programme" in RNM, from theoretical and practical point of view, we came to the conclusion that this world-accepted programme for combating cartels, does not apply in the territory of RNM. Collected data from the work of $\mathrm{CPC}$, the analyzed data collected from the companies registered in the territory of RNM, the CPC reports in the last 10 years, the reports of EC from 2020 for the development of the competition law in RNM etc., shows that "leniency" in RNM exists only as a law category. More preciously, leniency programme doesn't have practical dimension in fighting cartels.

Taking into account positive comparative experiences, the views of many experts concerning the advantageous of "leniency" and the need for its widespread use, at the same time, based on the fact that the implementation of this programme has great advantages in both large and small economy countries, we are of the opinion RNM, i.e the competent authorities must deal more seriously with this issue. Namely, when a certain concept or programme exists in the legislation and bylaws of a state, its success is determined by the capacity and will of the competent bodies to implement it.

RNM via CPC, should take concrete measures for promoting leniency, which according to our opinion should include organization of seminars, workshops, round tables and other educational events that will highlight the benefits of using this programme. They should focus on the business sector and other undertakings too, and explain the whole procedure, stages that encompass the same procedure, and finally, take all the necessary steps to make this program whit in reach of the undertakings.

In addition, the CPC should work on transmission of clear and comprehensive information and highlight the high fines that the CPC may impose, which should be the main incentive for undertakings to report a cartel. The mere interpretation of the provisions of the LPC and the Decree from 2012, does not provide with solutions and improvement of the situation regarding cartels. Despite the commission's claims that it has a small budget that limits its ability to exercise its legal powers, we hold the view that CPC may act on a better way to improve this situation. 
The analysis of the solutions contained in the LPC, the Decree, the guidelines, etc., creates the perception that the RNM thoroughly and comprehensively regulates the "leniency programme". Yet, this perception is relevant, only if the solutions are analyzed separately. However, analyzing this concepts comparatively and in relation to EU solutions, it is easy to see that the provisions, especially of the bylaws, should be clearer, more precise, and the most important to regulate more questions regarding the implementation of leniency. What is worth to be mentioned, for example, the Decree from 2012 speaks about marker system, in extremely deficient language, explaining it without giving a clear idea of the procedure, the position of the applicant since he will apply marker and etc. To achieve level of understanding, CPC may just take into consideration the point 15 of the 2006 Leniency Notice, and to implement it in the Decree.

This way Macedonian law predicts the notion, conditions and procedure for leniency, creates the impression that the Decree from 2012, and in general LPC in the part of leniency, are pro forma adopted provisions, established in the absence of real will to motivate companies to use leniency. Hence, the very low level of knowledge for leniency in RNM is not surprising. We can not expect effectiveness of this programme, given the fact that companies are not familiar with the basic concepts of it. For example, business sector, the concept of "added value", or "quality of evidence and accurate time frame" etc is unknown category. The undefining or inaccurate definition of these essential concepts contributes to the creation of "abuse" position, imposing the question: whether or not the conditions for using the benefits of the program are met.

Finally, in addition, companies have no idea about one of the most serious questions imposed in EU and worldwide competition law, such as the position of applicants in civil proceedings. How protected they are, whether they are in a discriminatory position in relation to the other participants in the cartel, given the fact that they have already given statements to the relevant body, etc. In circumstances when the EU and the world are discussing and working on taking concrete measures to increase the use of this programme, RNM treats the issue only as a legal conception. So, changes in this area must be done, and the CPC must take concrete measure to improve the situation regarding "leniency."

\section{REFERENCES}

\section{BOOK AND ARTICLES}

1. Buffer, B.W., Kafele, H.L., Fishbien S. Cartel leniency in United States: overview. Shearman \& Sterling LLP. Available from: [https://uk.practicallaw.thomsonreuters.com/4-501-2185?tr ansitionType $=$ Default\&contextData $=($ sc.Default $)$, Accessed 1 April 2021 
2. Dominte, O., \& Şerban, D., \& Dima, A.M., Cartels in EU: study on the effectiveness of leniency policy," Management \& Marketing, Economic Publishing House, vol. 8(3), 2013, pp.1-24

3. Ysewyn, J., Boudet, J., Leniency and competition law: An overview of EU and national case law Procedures, agreement, all business sectors, sanctions / fines / penal ties, leniency, foreword, Art. $\mathrm{N}^{\circ}$ 72355, 2018, [https:/www.covcompetition.com/wp-content/uploads/sites/21/2018/08/ here-1.pdf], Accessed 29 March 2021

4. Lacerda, Aranha. J. F., The Leniency Programs and the Creation of a One-Stop Shop for Markers, RDC, Vol. 2, no 2, 2014, pp. 64-75

5. Tusevska Gavrilovikj, B., Competition law in Republic of North Macedonia, Faculty of Law, Osjek, 2020

6. Palmigiano, P., Penny L., Competition law and coronavirus: what's the connection, 2020, available form: [https://www.taylorwessing.com/en/insights-and-events/insights/2020/04/competition-law-and-coronavirus-whats-the-connection], Accessed 28 March 2021

\section{EU TREATIES}

1. Article 101 (TEU) Lisbon

2. Article 102 (TEU) Lisbon

\section{COURT OF JUSTICE OF EUROPEAN UNION}

1. EU Canned Vegetables (Case COMP/AT.40127)

2. Forex (Case COMP/AT.40135)

3. Occupant Safety Systems (Case COMP/AT.40481)

\section{EU SECONDARY LEGISLATION}

1. Council Regulation (EC) No 1/2003 of 16 December 2002 on the implementation of the rules on competition laid down in Articles 81 and 82 of the Treaty

2. Commission Regulation (EU) 2015/1348 of 3 August 2015 amending Regulation (EC) No $773 / 2004$ relating to the conduct of proceedings by the Commission pursuant to Articles 81 and 82 of the EC Treaty

3. Directive 2014/104/EU of the European Parliament and of the Council of 26 November 2014 on certain rules governing actions for damages under national law for infringements of the competition law provisions of the Member States and of the European Union, available from: [https://eur-lex.europa.eu/legal-content/GA/TXT/?uri=celex:32014L0104], Accessed 5 April 2021

4. Directive 2014/104/EU of the European Parliament and of the Council of 26 November 2014 on certain rules governing actions for damages under national law for infringements of the competition law provisions of the Member States and of the European Union

5. Directive (EU) 2019/1 of the European Parliament and of the Council of 11 December 2018 to empower the competition authorities of the Member States to be more effective enforcers and to ensure the proper functioning of the internal market 
6. Directive (EU) 2019/1937 of 23 October 2019 of the European Parliament and of t

7. Council on the protection of persons who report breaches of Union law; Commission's Notice on co-operation within the network of competition authorities (OJ 2004 C101/43) (ECN Notice)

8. Consolidated version of the Treaty on the functioning of the European Union - part three: union policies and internal actions - title vii: common rules on competition, taxation and approximation of laws - chapter 1: rules on competition - section 1: rules applying to undertakings - article 101 (ex article $81 \mathrm{tec}$ )

9. Commission Notice on Immunity from fines and reduction of fines in cartel cases, Available from: [https://eur-lex.europa.eu/legal-content/GA/TXT/?uri=CELEX:52006XC1208(04)\# ntc1-C_2006298EN.01001701-E0001], Accessed 31 March 2021

\section{REPORTS}

1. OECD, The role of competition policy in promoting economic recovery, 2020, [www.oecd.org/ $\mathrm{daf} /$ competition/the-role-of-competition-policy-in-promoting-economicrecovery- 2020. pdf], Accessed 11April 2021.

\section{LIST OF NATIONAL REGULATIONS, ACTS AND COURT DECISIONS:}

1. Macedonian Law on Protection of Competition ("Official Gazette of the Republic of Macedonia" nos. 145/2010, 136/2011, 41/2014, 53/2016 and 83/2018

2. Decree RNM., бp:41/2012 from 26.03.2012, is available from: [https://dejure.mk/zakon/ uredba-za-pobliskite-uslovi-za-osloboduvanje-ili-namaluvanje-na-globata-i-postapkatapod-koja-komisijata-za-odluchuvanje-po-prekrshok-odluchuva-za-osl], Accessed 25 March 2021.

\section{LECTURES}

1. Snyder, B., Chief Executive Officer, Competition Commission of Hong Kong, China, OECD Competition Division, [https://www.youtube.com/watch?v=dJSNoWD0vb8], Accessed on 1 February 2020

\section{WEBSITE REFERENCES}

1. [https: //ec.europa.eu/competition/cartels/statistics/statistics.pdf], Accessed 25 March 2021

2. [https://ec.europa.eu/competition/cartels/whistleblower/index.html], Accessed 1 April 2021

3. [http://www.oecd.org/corporate/ca/1890449.pdf], Accessed 11 April 2021

4. [https://ec.europa.eu/competition/antitrust/coronavirus.html], Accessed 10 April 2021

5. [https://thelawreviews.co.uk/title/the-cartels-and-leniency-review/european-union], Accessed 1 April 20201

6. [http://kzk.gov.mk/category/konkurencija-obrasci-informacii-resursi/], Accessed 28 March 2021 